\title{
Assessment of Major Production Constraints and Common Diseases of Cattle in Selected Districts of East Wollega Zone, Western Ethiopia
}

\author{
Tesfaye Mersha *Dereje Bekele Tesfaye Mideksa Milkesa Gelana \\ Bako Agricultural research center, P.O.Box 03, Bako, Oromia,Ethiopia
}

\begin{abstract}
This study was under taken in selected districts of east Wollega Zone of Oromia region with the objective of assessing major cattle production constraints and common cattle diseases. Questionnaire was developed and designed in a simple manner to get accurate information and pre-tested on a small group of farmers. The major cattle production constraints and common cattle diseases were identified by a pilot study and raking technique and utilized to prioritize the listed production constraints and diseases. The study districts sampled purposively whereas 'kebeles' or "Ganda" were selected randomly and respondents were selected using systematic random sampling techniques. Thus, a total of 90 farmers were interviewed, accordingly. A single-visit- multi-subject formal survey technique was used. Finally, the data was analyzed with SPSS statistical software and constraints were ranked and quantified using Rank Based Quotient formula. Among the six listed constraints animal feed and grazing land shortage has been assigned rank number one (82.15\%) and animal health and veterinary service related problem was ranked second (81.04\%). And also among the fourteen mentioned cattle diseases, diseases that ranked first, second and third were trypanosomiasis $(82.65 \%)$, blackleg $(60.75 \%)$, and internal and external parasites $(54.9 \%)$, respectively. In conclusion, in this study animal feed and grazing land shortage and animal diseases were the main farmer's cattle production problems. Besides, majority of farmers were practicing poor animal husbandry that creates favorable environment for the disease multiplication and distribution in the communities. Therefore, further research has to put emphasis on this prioritized production constraints using reliable tools (laboratory finding supported) and introduction of improved forage species and strengthen the fodder development practices by providing continuous training.
\end{abstract}

DOI: $10.7176 / \mathrm{JBAH} / 9-11-04$

Publication date:June $30^{\text {th }} 2019$

\section{INTRODUCTION}

Ethiopia is heavily depending on agriculture sector which play a major role in overall economic development. Among the agricultural sectors, livestock is the one which is ranked first largest in Africa and tenth in the world (Hailu, 2014). Livestock provides a livelihood for $65 \%$ of the total population (Solomon et al., 2010), and $80 \%$ of the rural population of the country and contributes 15-17\% of Gross Domestic Product (GDP) and 35-49 \% of agricultural GDP and 37-87\% of the household incomes (Leta and Mesele, 2014). Therefore, an improvement this sector has the potential to contribute significantly to national income and to the welfare of the majority of rural families. Of the livestock species that are found in Ethiopia, cattle are the most important to the GDP of the country (Metaferia et al., 2011). Cattle are used as source of draught power for the rural farming population, supply farm families with milk, meat, manure, and also as source of cash income, playing a significant role in the social, and cultural values of the society (Ulfina et al., 2005, Melaku, 2011; Tonamo, 2016). According to recent estimation, Ethiopia has 60.39 million of cattle population (CSA, 2018; Beyi, 2016) and this figure clearly indicated how much cattle are key important sectors of agriculture which take part in a potential pathway out of poverty of many, particularly for rural farmers.

Regardless of the large number of cattle we have and very important source of economy in the country, the sector is characterized by low productivity. Income derived from this sector of agriculture couldn't bear significant role in the development of the country's economy due to many constraints mostly diseases. Cattle disease problems were extremely exacerbated by drought, concentration of livestock at watering points and dry grazing grounds combined with reduced resistance, intensifies the spread of contagious and parasitic diseases which often cause higher losses than the forage or water shortages (World Bank, 2001). Ethiopia was ranked highest among SubSaharan countries in livestock disease burden (Grace et al., 2012), such as in 2014/2015 fiscal year deaths estimated for Ethiopia due to various diseases were 3.23 million cattle, 4.37 million sheep and 4.90 million goats (CSA, 2015). There are numerous diseases of cattle that affect productivity and fertility of the sector in the country. This is, mainly due to absence of systematic disease surveillance \& reliable data. In addition lack awareness and poor practice among farmers. Assessment of major cattle production constraints and common cattle diseases have not identified in the current study area so far. Hence, identifying of cattle health constraints is valuable since used as an input for development of optimum prevention and controlling strategies, moreover, farmer's knowledge and practices towards the disease should be well-known. Therefore, the objectives of this study were assessing major 
livestock production constraints and common diseases of cattle then ranking based on economic importance as well as identifying the knowledge and practice of farmers towards the disease.

\section{MATERIALS AND METHODS}

\section{Study area}

The study was carried out in three districts namely Diga, Wayu Tuka and Boneya Boshe which are found in East Wollega zone of Oromia region, in western part of the country. East wollega zone is about $352 \mathrm{~km}$ distance from Addis Ababa. The average elevation of the area is $2017 \mathrm{~m}$ above sea level and has maximum and minimum temperature of $22.40 \mathrm{C}$ and $10.9 \mathrm{0C}$, respectively. The dry season of the study area ranges from April to June while the wet season is from October to December. The mean annual rain fall of the area ranges from $800 \mathrm{~mm}$ to $2400 \mathrm{~mm}$ (Moti et al., 2011). The agro ecologies of the study areas were woenadega for Wayu Tuka and Boneya Boshe districts and Dega for Diga district, and study was conducted from February to December 2016.
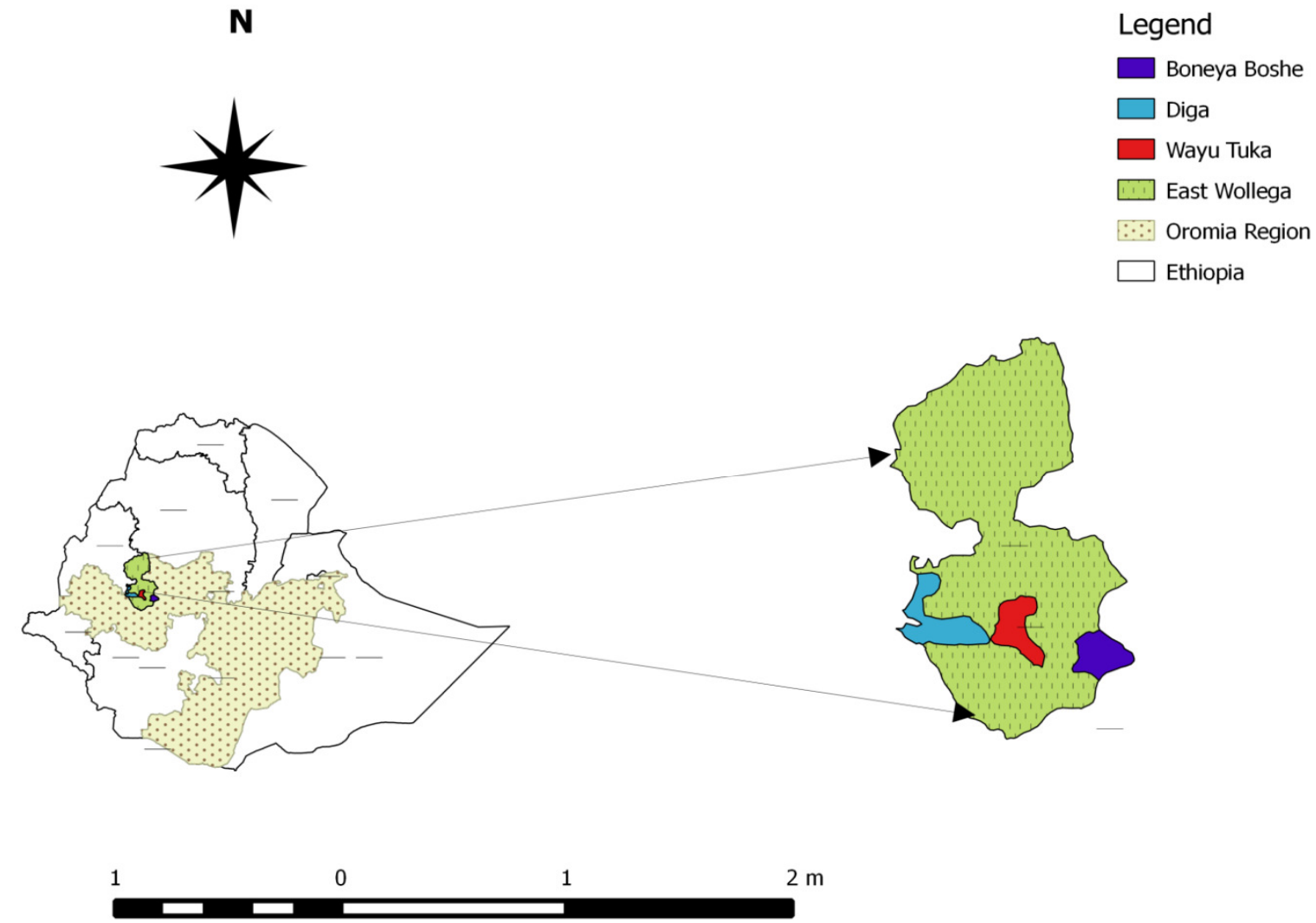

Figure 1: shows map of the study area

\section{Study Design and Methods}

The questionnaire was developed in accordance with the objectives of the study and designed in a simple manner to get accurate information from the farmers and then pre-tested on a small group of farmers. It was mainly based on socio-demographic characteristics of household, major cattle production constraints, the major cattle diseases, farmers knowledge and practice towards diseases as well as clinical symptoms perceived by the respondents were used for identification of a particular cattle disease. The major cattle production constraints and common cattle diseases were first identified by a pilot study and severity raking technique was utilized to prioritize the listed production constraints and common diseases of cattle's.

\section{Sampling techniques and sample size}

Three districts were sampled purposively based on cattle production potential and from each districts two PAs were randomly selected (totally 6 PAs were sampled). Then, farmers were selected using systematic random sampling methods. A total of 90 farmers were randomly selected from the three districts $(30$ farmers from each district \& 15 from each PAs). A single-visit- multi-subject formal survey technique was used to collect data (ILCA, 1990). Finally, the selected respondents were interviewed using pre-tested, structured questionnaire, accordingly.

\section{Data management and analysis}

The questionnaire data was entered into SPSS statistical software and analyzed using descriptive statistical tests. Finally, constraints that obtained from the farmers were ranked \& quantified using Rank Based Quotient (RBQ) formula developed by Sabarathnam and Vennila (1996). 


\section{$\mathrm{RBQ}=\sum \mathrm{f}_{\mathrm{i}}(\mathrm{n}+1-\mathrm{i}) \times 100 / \mathrm{N} \times \mathrm{n} \quad\{\mathrm{i}=1\}$}

Where, $\mathrm{fi}=$ frequency of respondents reporting a particular constraint under $\mathrm{i}^{\text {th }}$ rank;

$\mathrm{N}=$ total number of respondents; $\mathrm{n}=$ number of constraints identified;

$\mathrm{i}=$ rank of the attributes.

\section{RESULTS AND DISCUSSIONS}

Demographic characteristics, Herd size and structure of the respondents

A total of 90 households were involved in this study. The data on demographic characteristic profile of the respondents have been illustrated in Table 1 . The majority of the respondents were male $(97.8 \%)$ and the rest female (2.2\%). Regarding marital status of households, all respondents were married (100\%). The ages of respondents were ranges 20 to 80 with mean of $44.4 \pm 12.83$ years old. Regarding education status of the participants $(33.3 \%)$ of them had no formal education while $(66.7 \%)$ of them had formal education.

Table1: Socio-demographic characteristics of the respondents, livestock structure and size

\begin{tabular}{|c|c|c|c|}
\hline Parameters & Mean \pm SD (Min-Max) & Frequency & Proportion (\%) \\
\hline \multicolumn{4}{|c|}{ Gender of respondents } \\
\hline Male & - & 88 & 97.8 \\
\hline Female & - & 2 & 2.2 \\
\hline \multicolumn{4}{|l|}{ Marital status } \\
\hline Single & - & 0 & \\
\hline Married & - & 90 & 100 \\
\hline Divorced & & 0 & \\
\hline \multicolumn{4}{|c|}{ Educational Background } \\
\hline Illiterate & - & 30 & 33.3 \\
\hline Primary & - & 45 & 50 \\
\hline Secondary & - & 15 & 16.7 \\
\hline Age of respondents & $44.4 \pm 12.83(20-80)$ & - & - \\
\hline \multicolumn{4}{|c|}{$\begin{array}{l}\text { Livestock structure and size } \\
\text { owned per households }\end{array}$} \\
\hline Cattle & $8.77 \pm 8.16(0-50)$ & - & - \\
\hline Sheep & $1.7 \pm 2.46(0-15)$ & - & - \\
\hline Goat & $0.63 \pm 2.04(0-15)$ & - & - \\
\hline Mule & $0.04 \pm 0.21(0-1)$ & - & - \\
\hline Donkey & $1.09 \pm 1.08(0-4)$ & - & - \\
\hline Poultry & $6.47 \pm 6.58(0-30)$ & - & - \\
\hline
\end{tabular}

Identification of the majors' farmer's source of economy of the area

The farmers source of income of the study area have been mainly categorized into two major categories i.e., crop production and livestock rearing. In the present study farmer's source of income have been ranked and presented in Table 2. Thus, as the result indicates crop production has been graded by the respondents as rank number one $(98.97 \%)$ followed by livestock production (74.78\%) and others like off farm activities such as paid salary, labor and etc. were ranked as third $(50.32 \%)$.

Table 2: Ranking of farmer's source of income

\begin{tabular}{|c|c|c|c|c|c|c|c|}
\hline \multirow[t]{2}{*}{ Source of income } & \multirow{2}{*}{$\begin{array}{l}\text { Number } \\
\text { respondents }\end{array}$} & \multicolumn{6}{|c|}{ Rankings } \\
\hline & & First & Second & Third & Fourth & RBQ & Rank \\
\hline Crop production & 90 & 87 & 2 & 1 & - & 98.97 & $\mathbf{I}$ \\
\hline Livestock production & 90 & 3 & 85 & - & 2 & 74.78 & II \\
\hline Daily laborer & 90 & - & - & 4 & 86 & 26.13 & IV \\
\hline $\begin{array}{l}\text { Off farm activities (paid salary } \\
\text { etc.) }\end{array}$ & 90 & - & 3 & 85 & 2 & 50.32 & III \\
\hline
\end{tabular}

Major cattle production constraints of the area

In the present study major livestock production constraints have been identified and ranked, accordingly. Among the six listed production constraints that described by respondents during the pilot test, animal feed and grazing land shortage has been ranked number one $(82.15 \%)$ by the respondents which means that it is a major problem being faced by the farmers in the study area. Similarly, animal health and veterinary service related problem was ranked second (81.04\%), absence of improved breeds ranked as third (52.54\%), awareness or knowledge gab among the farmers $(49.78 \%)$ ranked fourth, drinking water shortage and impurity (42.74\%) was ranked fifth whereas a market problem (41.45\%) was ranked sixth. Summary of farmer's major production constraints were displayed in Table 3 as the following. 
Table3: Major livestock production constraints of the area

\begin{tabular}{|c|c|c|c|c|c|c|c|c|c|}
\hline \multirow[t]{2}{*}{ Production constraints } & \multirow{2}{*}{$\begin{array}{l}\text { No of res- } \\
\text { pondents }\end{array}$} & \multicolumn{8}{|c|}{ Rankings } \\
\hline & & First & Second & Third & Fourth & Fifth & Sixth & $\mathrm{RBQ}$ & Rank \\
\hline $\begin{array}{lcr}\text { Anima } & \text { health } & \text { and } \\
\text { veterinary } & \text { service } & \text { related } \\
\text { problems } & & \\
\end{array}$ & 90 & 30 & 25 & 32 & - & 2 & 1 & 81.04 & II \\
\hline $\begin{array}{l}\text { Animal feed and grazing } \\
\text { land shortage }\end{array}$ & 90 & 44 & 21 & 8 & 10 & 6 & 1 & 82.15 & I \\
\hline $\begin{array}{l}\text { Absence of improved } \\
\text { breeds }\end{array}$ & 90 & 6 & 20 & 10 & 20 & 14 & 20 & 52.54 & III \\
\hline $\begin{array}{l}\text { Awareness or knowledge } \\
\text { gab }\end{array}$ & 90 & 5 & 17 & 15 & 19 & 3 & 31 & 49.78 & IV \\
\hline $\begin{array}{l}\text { Water Shortage and } \\
\text { impurity }\end{array}$ & 90 & 2 & 5 & 17 & 16 & 28 & 22 & 42.74 & $\mathbf{V}$ \\
\hline $\begin{array}{l}\text { Infrastructure and market } \\
\text { related problems }\end{array}$ & 90 & 3 & 2 & 8 & 25 & 37 & 15 & 41.45 & VI \\
\hline
\end{tabular}

\section{Major cattle diseases that identified by respondents}

In this study respondents confirmed that diseases are one of the main constraints of their livestock production. About fourteen common cattle diseases that known locally by farmers were assessed during pilot test. Subsequently, the local names of diseases that listed were translated in to scientific /English name with the help of the nearby animal health workers of that area and finally ranked by respondents during questionnaire interview, accordingly. Hence, as the result showed among the fourteen mentioned cattle diseases, diseases that ranked first, second and third were trypanosomiasis $(82.65 \%)$, blackleg $(60.75 \%)$, and internal and external parasites $(54.9 \%)$, respectively and whereas infectious keratoconjuctivitis $(11.22 \%)$ was ranked last. The present study result in line with the report of Moges and Bogale (2012) during assessment of livestock disease has made in Lay-Armacheho district of northwestern Ethiopia, trypanosomosis (39.13\%) was ranked first in adult cattle.

Table 4: common diseases of cattle that ranked by respondents based on their importance

\begin{tabular}{|c|c|c|c|c|c|c|c|c|c|}
\hline \multirow{2}{*}{$\begin{array}{l}\text { List of diseases that } \\
\text { known by farmers }\end{array}$} & \multirow{2}{*}{$\begin{array}{l}\text { Number of } \\
\text { respondent }\end{array}$} & \multicolumn{8}{|c|}{ Rankings } \\
\hline & & First & Second & Third & Fourth & Fifth & Sixth & $\mathrm{RBQ}$ & Rank \\
\hline Masa (FMD) & 90 & 2 & 3 & 1 & 5 & 4 & 11 & 21.55 & XI \\
\hline $\begin{array}{l}\text { Hudha/Gororsisa } \\
\text { (Pasturellosis) }\end{array}$ & 90 & 2 & 10 & 8 & 7 & 4 & 13 & 38.52 & $\mathbf{V}$ \\
\hline $\begin{array}{l}\text { Jito,silmi (Internal and } \\
\text { external parasites) }\end{array}$ & 90 & 11 & 9 & 12 & 13 & 11 & 3 & 54.9 & III \\
\hline Gandi (Trypanosomiasis) & 90 & 54 & 11 & 4 & - & 9 & 1 & 82.65 & I \\
\hline Goga lukisa/Citesa (LSD) & 90 & 1 & 8 & 13 & 12 & 4 & 10 & 42.36 & IV \\
\hline $\begin{array}{l}\text { Bishoftu/Cacabsa/Aba- } \\
\text { gurba (Blackleg) }\end{array}$ & 90 & 3 & 30 & 17 & 8 & - & 5 & 60.75 & II \\
\hline $\begin{array}{l}\text { Aba-sanga/cita/Dingetegna } \\
\text { (Anthrax) }\end{array}$ & 90 & 1 & 6 & 10 & 8 & 7 & 1 & 29.95 & VIII \\
\hline Dhiga fincesisa (Babesiosis) & 90 & 1 & 2 & 5 & 1 & 10 & 4 & 19.53 & XII \\
\hline $\begin{array}{l}\text { Somba } \\
(\mathrm{CBPP}, \mathrm{TB})\end{array}$ & 90 & 2 & 5 & 3 & 17 & - & 16 & 36.33 & VI \\
\hline Dhukuba Mucha (Mastitis ) & 90 & 3 & 1 & 2 & 1 & 12 & 10 & 23.68 & $\mathbf{X}$ \\
\hline Gara bokoksa (Bloat) & 90 & 10 & 4 & 4 & 2 & 2 & 2 & 23.7 & IX \\
\hline $\begin{array}{l}\text { Gatachisa } \quad \text { (reproductive } \\
\text { diseases) }\end{array}$ & 90 & - & - & 11 & 10 & 10 & 5 & 30.58 & VII \\
\hline $\begin{array}{ll}\text { Araba } & \text { Korati } \\
\text { (Actinobacillosis) } & \end{array}$ & 90 & - & - & - & 1 & 15 & 3 & 14.85 & XIII \\
\hline Bosisa (infectious & 90 & - & 1 & - & 5 & 2 & 6 & 11.22 & XIV \\
\hline $\begin{array}{l}\text { keratoconjuctivitis, eye } \\
\text { worm) }\end{array}$ & & & & & & & & & \\
\hline
\end{tabular}

\section{Farmers' knowledge and practice towards cattle diseases}

Majority of the respondents $(97.8 \%)$ were encountered animal health problems. However, very few of the respondents had aware of the possible source and prevention of methods of different diseases. On other hand majority of the participants had basic knowledge on treatment of diseased animal such as $84.4 \%$ of respondent's choice present to veterinary clinics. Regarding to farmers practices, majority of the respondents were carrying out poor animal health management systems. For instance, few of participants (28.9\%) followed appropriate disposal 
of dead animals. Generally in this study majority of the respondents were familiar with signs of cattle diseases (Table 5).

Table 5: Farmers knowledge and practice related to animal health problems

\begin{tabular}{|c|c|c|}
\hline Farmers knowledge and practice towards to diseases & Frequency & Percentage $(\%)$ \\
\hline \multicolumn{3}{|l|}{ Do you have animal health problems in you areas? } \\
\hline Yes & 88 & 97.8 \\
\hline No & 2 & 2.2 \\
\hline If yes what do you think the cause of problems? & & - \\
\hline Diseases prevalence & 50 & 55.6 \\
\hline Shortage grazing land & 26 & 28.9 \\
\hline Unavailability of veterinary service & 13 & 15.5 \\
\hline \multicolumn{3}{|l|}{ What do you suggest the solution of problems? } \\
\hline Animal health service should be improved & 26 & 28.9 \\
\hline Better drugs and extension service should be delivered & 17 & 18.9 \\
\hline Regular vaccination and establishment vet. Clinics & 19 & 21.1 \\
\hline The government should pay attention to the problems & 8 & 8.9 \\
\hline Improved animal feed and health service must applied & 14 & 15.6 \\
\hline I do not know & 6 & 6.6 \\
\hline \multicolumn{3}{|l|}{ What symptoms of diseases frequently observed? } \\
\hline Coughing & 15 & 16.1 \\
\hline Diarrhea & 21 & 23.88 \\
\hline Salivation & 1 & 1.1 \\
\hline Rough hair coat & 12 & 13.9 \\
\hline Difficulty of breathing & 20 & 22.78 \\
\hline Anorexia & 5 & 5.5 \\
\hline Depression & 6 & 6.7 \\
\hline I do know & 19 & 22.49 \\
\hline \multicolumn{3}{|l|}{ What are major practice when animal diseased? } \\
\hline Present to veterinary clinics & 76 & 84.4 \\
\hline Present to traditional healers & 1 & 1.1 \\
\hline Left as it is & 2 & 2.2 \\
\hline Using both modern and traditional treatment & 11 & 12.2 \\
\hline \multicolumn{3}{|l|}{ What do you do if the animal dies of disease? } \\
\hline Remove the skin and throw to field & 30 & 33.3 \\
\hline Burring or burning the dead body & 26 & 28.9 \\
\hline Throw to field without removing the skin & 34 & 37.8 \\
\hline
\end{tabular}

\section{CONCLUSIONS AND RECOMMENDATIONS}

In the present study six major livestock production constraints as well as fourteen common diseases of cattle were identified and ranked, accordingly. Thus, animal feed and grazing land shortage, and anima diseases were the main farmer's cattle production problems of the study area. Besides, majority of farmers were practicing poor animal husbandry that creates favorable environment for the disease multiplication and distribution in the communities.

Therefore, based on the above conclusion the following recommendations were forwarded:

- Further investigation using reliable tools (laboratory supported) likes microbiological, parasitological and molecular techniques are needed in order to know the exact epidemiological scenario of each disease

- Every responsible bodies have to put emphasis on farmers prioritized production constraints, accordingly

- The farmers should be made aware of about the diseases particularly the economic importance, transmissions methods, and controlling techniques through veterinary extension education and possible means like media.

- Introduction of improved forage species and strengthen the fodder development practices by providing continuous training and linking to strategic feeding practices.

- Introduction of appropriate crop residue management (urea/effective microorganism treatment) and fodder conservation methods when green feed is in excess during wet seasons.

- Provide farmers with training on appropriate utilization of available feed resources and establishment and use of improved forages.

- Provision of strong extension services and training on improved forage and fodder trees will be better options. 


\section{REFERENCES}

Beyi, A. F. (2016): Feed the future innovation lab for livestock systems Ethiopia, the Animal Source Food Production and Marketing Brief., Doctoral dissertation at the University of Florida.

CSA (2015): Central statistical agency (CSA). Report on livestock and livestock characteristics (private peasant holdings), Agricultural Sample Survey 2014/15 [2007 E.C.], Volume II, bulletin 578, Addis Ababa, Ethiopia. Pp: 9-15.

CSA (2017): Central statistical agency (CSA). Report on livestock and livestock characteristics (private peasant holdings), Agricultural Sample Survey 2016/17 [2009 E.C.], Volume II, bulletin 579, Addis Ababa, Ethiopia. Pp: 6.

Grace, D., Mutua, F., Ochungo, P., Kruska, R., Jones, K., Brierley, L., Lapar, L., Said, M., Herrero, M. And Phuc, P.M., Thao, N.B., Akuku, I. and Ogutu, F. (2012). Mapping of poverty and likely zoonosis hotspots. Zoonoses, ILRI; Project 4. Report to the UK Department for International Development. Nairobi, Kenya

Hailu, S. 2014: A broken Value chain: Why Ethiopia imports livestock products while it ranks first in Africa in resources? Topic Tweet., No.16

Leta, S. and Mesele, F. (2014): Spatial analysis of cattle and shoat population in Ethiopia: growth trend, distribution and market access. Springer plus. 3: 310 .

Melaku, T. (2011): Oxidization versus tractorization: Options and constraints for Ethiopian framing system. Int. J. Sustainab. Agric., 3: 11-20.

Metaferia, F, Cherenet, T, Gelan, A., Abnet, F, Tesfay, A, Ali, J. A. and Gulilat, W. A. (2011): Review to improve estimation of livestock contribution to the national GDP. Ministry of finance and economic development and ministry of agriculture Addis Ababa, Ethiopia,

Moges,N and Bogale,B (2012): Assessment of Major Animal Production and Health Problems of Livestock Development in Lay-Armacheho District, Northwestern Ethiopia, and American-Eurasian Journal of Scientific Research 7 (3): 136-141.

Solomon, et al (2010): Sheep and Goat Production Systems in Ethiopia, Ethiopian sheep and goat Productivity improvement program

Tonamo, A. (2016): A review on cattle husbandry practices in Ethiopia. Intern. J. Livestock Prod., 7: 5-11.

Ulfina, G., Zelalem, B., Jemal, D., Gemeda, D., Chala, M., Jiregna, D., Diriba, G., Lemma, G., Workneh, A. and Adam, D. (2005): Survey of cattle production and marketing practices in Danno District, Western Ethiopia, using PRA tools. PRA Report.

World Bank (2001): Pastoral area development in Ethiopia: Issues paper and project proposal, 1818 H Street, N.W. Washington, D.C. 20433, U.S.A. 